\title{
REVIEWS
}

\section{Andrew Weiss}

\section{Treasures from Trash}

Kelsi Nagy and Philip David Jonson II, eds. Trash Animals: How We Live with Nature's Filthy, Feral, Invasive, and Unwanted Species. Minneapolis: University of Minnesota Press. Xvi + 314 pp. \$24.95. Pbk.

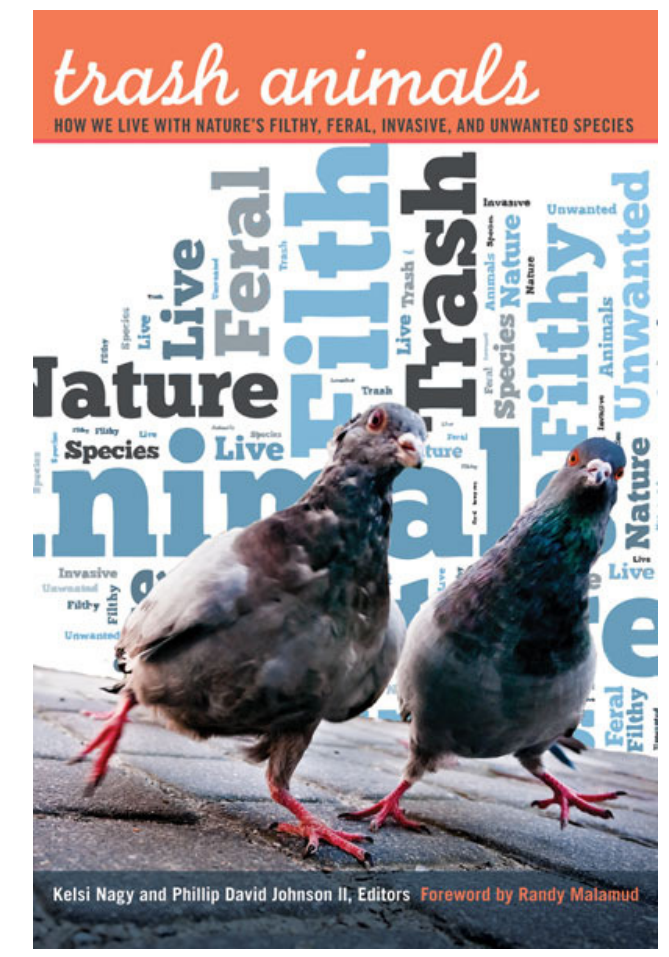

Trash Animals offers a close look at a variety of animal species that are widely treated in an uncritical and destructive manner. In the process, it makes a compelling case for the practical necessity, ethical worthiness, and genuine difficulty of gaining an informed perspective on species by whom humans are surrounded and with whom we are often in conflict. Some readers might bemoan the lack of unambiguous programmatic solutions. Ultimately, however, this informative collection offers compelling critical resources for confronting challenging situations that persist in their ambiguity despite careful and attentive critical thinking. Trash Animals imparts a valuable lesson for dealing with the messiness of human relations with animals that do not fit neatly into easily managed domestic spaces or easily dignified wilderness. 
Trash Animals makes a unique contribution to animal studies scholarship in at least three ways. First, the collection addresses a range of species with whom humans have problematic relations, providing insights unavailable to individual case studies, and doing so in an informative, memorable, and provocative way. Second, it shows a spectrum of consequences that can follow from confronting those problem species, not all of which are positive. Third, the collection explores the entangled cultural and emotional complications of these problematic encounters.

The editors use the term "trash animals" to designate a category of animals met day to day that are seen as invasive, threatening, disgusting, or otherwise undesirable - and that are widely considered disposable. It is a term of derision borrowed from fur trapping industries (as when a non-target species like a skunk is caught in place of a bobcat, making the skunk a "trash animal"), which the editors repurpose for a critical project on behalf of the very animals derided by it. Trash Animals provokes us to challenge our own thinking about the many specific species covered in its pages, and to appreciate the complex cultural and biological history of similar species treated like trash. Each contributor explores a particular species, scrutinizing its cultural history and associations, its mode of life and ecological niche, separating widespread misinformation from an obscured and usually non-threatening truth.

Outside the foreword and editor's introduction, the book's 17 short texts are grouped into five sections: I. The Symbolic Trash Animal, II. The Native Trash Animal, III. The Invasive Trash Animal, IV. The Urban Trash Animal, and finally V. Moving Beyond Trash. While the contributions do not explicitly address these categories, they raise interesting questions about their themes and trouble their categories in provocative ways. Considering gulls, wolves, snakes, and locusts, the Symbolic section repeatedly shows the painfully enduring power of misinforming myth. Considering coyotes, prairie dogs, and packrats, the encounters addressed in the Native section show what can happen when a species impinges on one's home or environs. Considering Canada geese, starlings, and carp, the Invasive section shows just how precarious a species' "desirable" status can be. Each of these species was the focus of quite deliberate planning protection for the geese, introduction to North America for the latter two - but each came to be maligned for adapting too well to their surroundings. The Urban section treats cockroaches, magpies, and pigeons, noting quite a range of distance in our relations - magpies appearing at a safe distance, cockroaches decidedly not, and pigeons caught somewhere in the middle. Andrew D. Blechman's piece on pigeons,

Humanimalia: a journal of human/animal interface studies

Volume 6, Number 1 (Fall 2014) 
perhaps the most thorough of the book, involves a broad and colorful cast of conflicting characters drawn from a larger book project simply called Pigeon. The first two chapters of the final section, Moving Beyond Trash, consider the possibilities of aesthetic beauty in the supposed ugliness of the bullhead catfish and the viscerally disgusting self-defense response of the lubber grasshopper, who vomits and defecates on those who threaten it. The final chapter, Kathleen Dean Moore's "The Parable of the Mice and the Rats," is the most expressly philosophical and the most productively meandering, eschewing the single-species focus of the rest of the other articles. The editors wisely opt not to try to tie up the collection's loose ends; instead, Moore's piece provocatively asks us to consider how we develop a sense of responsibility for the world around us, and to challenge the culturally dominant economistic models for evaluating the world and our responsibilities.

The introduction and the final essay are both marked by an unabashed ethical hopefulness, but the collection as a whole seems to me to tell a story that is more complicated and uncomfortable. While I sympathize with the editors' desire "to consider new relationships between humans and conflict species" (25), the "realities of these relationships" referred to by the editors in the same sentence involve unresolved problems that need to be addressed.

Part of what makes Trash Animals so compelling is that an important and uncomfortable insight emerges when all of these various encounters with different species are brought together: that there are times when we encounter a problematic interspecies relation that we simply do not know how to resolve ethically. This is what Donna Haraway in When Species Meet and elsewhere thinks through with figures of indigestion. While the essays in Trash Animals admirably address the problems of ethical success and failure in dealing with abject animals, some are more successful than others, and some end in a kind of trenchant ambiguity, where it is not at all clear how one might even proceed in imagination.

Some of the stories end happily ever after, as it were, convincingly dispelling harmful misinformation. This is the case with Kelsi Nagy's "Prairie Dog and Prejudice," which dispels the widespread notions that prairie dogs steal allegedly scarce grass needed for grazing cows and sheep, while digging burrows that threaten to break the legs of unsuspecting horses trotting through them. Nagy demonstrates that grazers actually 
prefer grass that has been pruned by prairie dogs who leave softer grasses to their taller cohabitants, while the eyesight and evolutionary history of horses suggests that they easily avoid small burrows. Nagy concludes that prairie dogs are welcome inhabitants of her now bustling ranch; for her, prairie dog-less ranches are "ghost towns." Prairie dogs, ranchers, horses, and grazers can all peacefully live happily ever after on the same property. The problematic relation with apparent "trash" animals is simply repaired by careful thinking and research. Not all encounters with trash animals end so well.

Bruce Barcott's "Kill the Cat that Kills the Bird?" tells the story of feralized house cats who have taken residence under a bridge where endangered birds are nesting; a zealous birder kills two of these cats with a rifle to defend the birds; many other birders rally to the cause, while defenders of cats are outraged and take legal action. The case itself is dismissed at an impasse, and it raises the larger question of how to care ethically for two irreconcilable species, here predator and prey, one "trashed" as feral and the other treasured as endangered. Barcott identifies a conflict between protecting species versus protecting individuals - often seen in scholarship between ecological concerns and animal rights. In this case, the gun-toting birder claims he is justified in sacrificing allegedly insubstantial numbers of a plentiful species in order to protect an endangered one. But even for those who wish to settle the matter individually, a conflict remains: between a bird with an interest in living by not being eaten, and a cat with an interest in living by eating birds. Feeding the cat in another way merely delays the problem, shifting the burden to chickens, fishes, or other farmed animals. From either perspective, some species or at least some individuals are rendered disposable - that is, they become trash animals. Tje essay is wise to open the problem without pretending to offer a clear solution, forcing us to confront the conflicts in ourselves and with others.

A third kind of case is significantly more brutal than the last, where little or no improvement is made in relating to other living animals. The stories that best fit this description here are those about cockroaches and packrats. In "Metamorphosis in Detroit," author Carolyn Kraus, a self-professed vegetarian pacifist eco-feminist, vows to find a harmonious relationship even with cockroaches. Exhausted after several unsuccessful creative experiments, she is compelled call an exterminator. Kraus concludes that it is possible to love a fictional or theoretical roach for its resilience and adaptability, but impossible to do so when faced with a live one. The fate of the packrats in Michael P. Branch's “Nothing Says Trash Like Packrats: Nature Boy Meets

Humanimalia: a journal of human/animal interface studies

Volume 6, Number 1 (Fall 2014) 
Bushy Tail" is similar. In a rather brutal scene I won't recount here, Branch, in whose house these packrats have begun to settle, ends up killing many of them, despite a newfound respect for their way of life informed by his research. While both authors have meditative moments of well-informed admiration for these species - and, indeed, inspiring them in the reader as well - not much has changed from the perspective of these other species. The packrats nearby the author's house are spared, it must be said, despite a zealous neighbor urging a hunting mission in a 500-meter radius. Nevertheless, as Branch writes, he "became a cold-blooded killer of [his] fellow creatures" (147). The editors of Trash Animals aim to "[add] to the growing conversation about conflict species in culture and [to open] the door for further conversations and scholarship" (21). They hope to "[create] a conversation where people can conceive of solutions that move beyond dichotomies" (23), as for example the familiar one between environmental ethics and animal rights. Even these "cold-blooded" stories then should be read as important contributions, widely representative and even positively thoughtful by comparison to average encounters with these animal others. But insofar as the collection encourages "making an effort to shift to an animal's point of view," (10) and "to conceive of better, more effective, more humane solutions for humanwildlife conflicts" (24), some of these encounters fall short.

What do we learn from them? I want to suggest that even if conflicts with these two specific species had been solved eventually - let us imagine a future in which cockroaches and packrats alike can be peacefully lured out of a house, which would then be easily sealed off, to new homes on their own - such encounters remain structurally unresolved. Moments like this will arise again. Rather than deciding once and for all that Kraus or Branch were either justified or heinous for killing their respective home-invaders, we can mourn these apparently unavoidable deaths while trying to find better solutions. What can we learn more specifically? That research and experimentation is still worthwhile, even if occasionally futile. As the editors write in the introduction: "If no peaceful way can be found to coexist with some animals, at least much can be learned from a thorough understanding of the conflict, not only about the nature of species but also about human aesthetics, evolution, and the limits of moral thought and action." (18) Even if Kraus's experiments in trying to peacefully lure cockroaches out of hiding with beer ended unsuccessfully, her experimental ethic is admirable and worth emulating - she did as much research as she could and ventured 
unconventional solutions for the sake of other animals. We must stay with the trouble, then, and try our best - without wasting time blaming and shaming others for unsuccessful attempts.

Trash Animals takes a unique place among related scholarship through its emotional charge, powerfully communicated in the writing style employed by all the authors. While each piece has its own idiosyncratic voice, they all share personal intimacy. Grounded in a specific place - almost exclusively in the United States it must be said, though Canada and South Korea make a single appearance each - all the texts have a conversational feel, making them readily accessible. While that personal, anecdotal, and occasionally poetic style is in good company with classics like Aldo Leopold's Sand County Almanac, Trash Animals sets itself apart not only by the diversity of contributors and the species they cover, but by the severity and strangeness of the encounters. The editors nicely position the collection with respect to Leopold's text, favorably citing his remark that while the great majority of species may have no economic value, the "stability" and "integrity" they contribute to their ecosystems entitles them to continued existence. Like Leopold, then, the contributors and editors of Trash Animals try to show the dignity of under-appreciated species. The contributors are doing something particularly interesting, insofar as they're trying to establish the dignity of those animals whose dignity is unreflectively denied by other humans. The denial of dignity to these other animals is the source of the very concept of "trash animals"; as the editors write in the introduction, "the term 'trash' opens up a moral loophole" (9) with which to justify violence.

The authors often meet these "trash" animals in settings whose stability and integrity seems undermined by them - a home, a river, a city, or elsewhere. This is what I mean by the strangeness and severity of the encounters: they often do not take place at a safe distance. "Trash animals" disturb precisely because they come too close for human comfort - as when cockroaches emerge from an old television in Kraus's home, or packrats take the pacifier of Branch's child. Many cases are less severe than those two, less directly threatening - pigeons congregating en masse in busy cities, Bullhead catfish swimming through muddy river waters, or Canada geese honking on lawns. They all nonetheless appear in spaces in which we live. Because they disturb many people on such a visceral and personal level, it is both fitting and compelling that Trash Animals should consistently adopt such a personal and intimate style; intimacy allows the authors to raise critical questions precisely at the moment of overwhelming

Humanimalia: a journal of human/animal interface studies

Volume 6, Number 1 (Fall 2014) 
emotions - disgust, insecurity, discomfort - that normally foreclose any such questioning. It may be difficult to ask critical questions when a cockroach is skittering across your floor or you can barely hear yourself think over an evening chorus of starlings in your yard, but the next best thing would be to have a writer walk you through such an encounter and to ask critical questions there. By having these feelings documented and reproduced we can revisit and rethink them, preparing ourselves to avoid being caught off guard, with the hope of "developing better, more humane, more effective solutions" (24).

As many of the essays show, fear and disgust are powerful forces for perpetuating myths that figure these species as threatening, out of control, and immediately worthy of destruction. Whether it is the alleged appetites of coyotes, belligerence of diamondback snakes, health hazards of pigeon droppings, dangers of prairie dens to horses, appetite for livestock of coyotes, so many of the widely believed threats of trash animals are extremely overstated or outright false. The editors and contributors "ask readers to set aside their preconceived notions and anthropocentric concerns for a moment and consider the realities of other living beings in a new light" (24), which might dispel destructive feelings of fear and disgust. This link between emotion and knowledge also works in the other direction - knowledge imparted by careful research can lead to different and much calmer emotions. As Lisa Couturier writes of coyotes in "One Nation Under Coyote - Divisible": "I want to say to those willing to shoot at the unknown - to shoot at what is perceived as a threat - that perhaps certain explicit information would calm their fears" (111). Couturier is appropriately tentative; tensions do run high as coyotes and many other species continue to be exterminated in alarming ways, as we see throughout the collection.

Few if any of these cases show much progress being made at the cultural level, but their resources for reimagining personal encounters are compelling. The tentativeness shown by Couturier and other contributors reveals an important aspect of the collection's contribution. Those who feel responsible for other animals must find ways of reaching those who do not. Trash Animals offers valuable resources for such discussions, which will be unavoidable if any of these species are to have a hope of better relations with humans. To take a personal example, even prior to reading this collection I had no trouble admiring city pigeons for all sorts of reasons. But plenty of people do have 
trouble, as Blechman's piece "Flying Rats" attests, and I admit I have been caught flatfooted as to how to respond to the hostility expressed about them. Trash Animals offers a close look at these kinds of emotional reactions and how they work-their justifications, often ill-informed, and the overblown proportions many myths reach-giving a set of important resources for anyone who wants to make the case (to other humans) for these animals and others like them. Against complaints that pigeons are "filthy" or that their droppings are hazardous, I can now reply that they offer no more hazard than owning a cat, perhaps even less, given that city-dwellers tend not to get as close to pigeon droppings as cat-owners do to litterboxes. Moreover, to those who advocate poisons and other forms of "pest-control," the British non-profit Pigeon Control Advisory Service (PiCAS) 's model of offering shelter and food to city pigeons away from busy public sites has shown impressive results-a case where hospitality shows more promise than animosity. Such pragmatic rebuttals abound in Trash Animals, many of which are surprising, detailed, and urgent.

Trash Animals can be read as both a contribution to current scholarship and a preparation for a great deal of work that remains to be done. It provides a starting point for thinking about a set of problems - concrete ethical problems encountered each day - by developing the general concept of the "trash animal," while examining many concrete cases in which that concept is at work. The collection offers a set of transferable practices. Already since reading the book I have found myself becoming more mindful of my relationships with the moths, centipedes, and squirrels, and preparing to have real conversations on their behalf.

Trash Animals offers a series of exhortations to slow down, think carefully, gain perspective and patiently widen our range of possible emotional responses, precisely at the moments where this can be the most difficult, but also most urgent: when we are emotionally overwhelmed by fear, disgust, or entitlement. It offers a detailed, pragmatically useful, and widely accessible set of stories and resources to think through these challenges in all their ambiguity and complex emotional depth. It's a welcome surprise that a book about difficult encounters should be such a great pleasure to read, even as it provokes and unsettles. Don't be afraid to dig through this trash heap: you're sure to find many unexpected treasures, even if everything unavoidably gets messy.

Humanimalia: a journal of human/animal interface studies

Volume 6, Number 1 (Fall 2014) 


\section{Works Cited}

Blechman, Andrew D. Pigeons. New York: Grove Press, 2006.

Haraway, Donna. When Species Meet. Minneapolis: U Minnesota P, 2007.

Leopold, Aldo. A Sand County Almanac: With Other Essays on Conservation from Round River. New York: Oxford UP, 1966. 